\title{
For Sally
}

Who knows the creatures that live under rocks, and where wildflowers grow, and the things that goats can say to you, and how to laugh ... . 
THIS PAGE INTENTIONALLY LEFT BLANK 
It is storied of that Prince, that having conceived a Purpose to invade Italy, he sent for Cineas, a Philosopher and the Kings friend: to whom he communicated his Designe, and desired his Counsel. Cineas asked him to what purpose he invaded Italie? He said, To Conquer it. And what will you do when you hav Conquerd it? Go into France said the King, and Conquer that. And what will you do when you have Conquerd France? Conquer Germany. And what then? said the Philosopher. Conquer Spain. I perceive said Cineas, you mean to conquer all the World. What will you do when you have conquerd all? Why then said the King we will return, and Enjoy our selvs at Quiet in our own Land. So you may now said the Philosopher without all this adoe.

thomas traherne: The Centuries, I, 22 
THIS PAGE INTENTIONALLY LEFT BLANK 
A part of this book was written on time made available by a grant from the Rockefeller Foundation, for which I am lastingly grateful. 
THIS PAGE INTENTIONALLY LEFT BLANK 